\title{
INFORMATION SKILLS: \\ THE REFLECTIONS AND PERCEPTIONS OF STUDENT TEACHERS AND RELATED PROFESSIONALS
}

\author{
Kay Wilson \\ The School of Information and Media \\ The Robert Gordon University \\ 352 King Street \\ Aberdeen, AB24 5BN UK \\ E-mail: k.wilson@rgu.ac.uk
}

\begin{abstract}
Part of the "information rich but knowledge poor" discussion concerns physical access to information, but another aspect relates to whether people can use the information they have accessed effectively. In education this is in relation to pupils, but it also concerns teachers. If teachers fail to understand the value and relevance of information skills to themselves as learners, will this create problems in developing those skills in their own pupils?

This paper focuses on interviews with (1) professionals who have expectations of student teachers regarding information skills, (2) student teachers reflecting on their own information skills. The data is set within the context of information skills development and the present teacher training ethos in Scotland. Results so far indicate three main issues: first, a lack of understanding about the term information skills; second, a general inability to view information skills as generic skills in a holistic way; and third, an inability and/or lack of opportunity, in many cases, to reflect on abilities and shortfalls.
\end{abstract}

\section{BACKGROUND}

Information literate individuals are "able to recognize when information is needed and have the ability to locate, evaluate and use effectively the needed information. Ultimately information literate people are those who have learned how to learn." (American Library Association, 1989, p.1) To be able to identify, locate, analyze, evaluate and use information in an effective and efficient way is increasingly regarded as essential during every stage of life; in formal education (Heaney, 1986; Avann, 1985; California Media and Library Educators Association, 1994; Healey, 1992), in the workplace (Labour Market and Skills Trends: 1996/1997, 1996) and in relation to everyday decision making. Commitment to the development of such skills should come both from the learner and from those involved in educating others to become flexible learners, i.e., teachers.

Despite the fact that these skills are recognized as vital, there is still confusion surrounding their development. The Information Search Process based on Kuhlthau's research (1995) illustrates the need for learners to develop knowledge about the learning process and their own individual learning styles and strategies. Taking a holistic view of the information-saturated world might aid a true understanding of information skills and what they mean in our own learning experiences.

In the 1970s, the focus was largely on library skills which aided users to make more effective use of the library - using the catalogue, familiarization with library routines and so on. Although useful, they only dealt with the tip of the iceberg as far as effective use of information was concerned. The move away from library skills came with writers such as Winkworth (1977) who, in reviewing the literature on this subject drew up a list of skills in relation to the research process.

The need to be able to deal with ever growing amounts of information involves developing skills much broader than being able and confident to locate and access sources (Eisenberg \& Brown, 1992). Cognitive skills need to be developed in all learners for the effective exploitation of 
information and it was within the education field that the need for these skills to be embedded in the learning experience was first highlighted.

By the 1980's the quantity of information available for consultation had grown immensely along with the broadening of the presentation media and formats, for example on-line information, CD-ROM; and increasingly in the 90s, the Internet.

The term 'information skills' was first used in the UK by Marland (1981) to cover the practical and cognitive skills associated with the effective use of information. Subsequent writers and researchers such as Hounsell and Martin (1983), Lincoln (1987), Howard (1991), and Irving (1992) have also used the term.

The term information skills, although not synonymous with information technology skills, does indicate overlap (Carter \& Monaco, 1987). Many information sources are increasingly technology based (Greensfeld \& Friedler, 1996). For example, the ability to search multimedia encyclopedias requires the ability to develop appropriate search strategies and it is clear from recent research that the use of information technology, with particular reference to teachers, is still causing problems (Wild, 1996; Times Educational Supplement (Scotland), 1994; Ridgway \& Passey, 1996). Although much has been written about what information skills are and how they should best be taught (Rogers, 1994; Herring, 1996), little research has focused on the teachers who, it is assumed, will have information skills capabilities.

\section{CURRENT SITUATION IN SCOTTISH SECONDARY SCHOOLS}

The importance of developing information skills has been highlighted by many individuals and also many influencing bodies (Book Trust, 1991; Dubber, 1995). In Scotland, The Scottish Office Education and Industry Department (1991) have also provided guidelines to Scottish secondary schools. Increasingly, in the formal education structure there is a need for pupils to be able to handle increasingly more complex information in an effective manner. There have been a range of curriculum developments in the last ten years in Scotland whose emphasis has highlighted the need for pupils to develop information skills.

One example is, the 5-14 Curriculum Development Programme for pupils aged 5-14 years. This curriculum change affects both primary and the first two years of secondary education. There is general acceptance that these skills are both useful and necessary, and need to be developed from an early age. In accordance with this, 5-14 states that pupils need to develop skills related to "planning, 'collecting evidence', 'recording and presenting' and 'interpreting and evaluating' (Scottish Office Education and Industry Department [SOEID], 1993). This trend is carried through Standard Grade examinations (16 year olds) and Revised Highers (17 year olds) (Scottish Examination Board, 1995). It will also be echoed in the aims of Higher Still, the latest curriculum development program for pupils aged $16+$.

These curricular changes seek to move the emphasis from teacher led teaching to pupil oriented learning: there is more emphasis on teachers being facilitators and pupils taking more responsibility for their own learning. Pupils are required to carry out investigations about topics chosen by themselves. They are, in theory at least, encouraged to look to the wider information community for sources of information, not only the school library and departments.

In Scotland, the curriculum documentation alludes to the need to develop information skills in pupils. It also makes an unstated assumption that teachers will have these skills themselves and will effectively develop these skills in the pupils under their instruction (SOEID, 1993b; SOIED, 1993c; SOEID, 1996)

\section{INFORMATION SKILLS TEACHING IN SCOTLAND}

The 'traditional' approach to skills development, in Scotland at least, has been in the past to teach library skills to S1, and study skills to S5 and S6 pupils. The problems with this approach is that there is no reinforcement of skills between S1 and S5 either by the librarian in a structured way or by teachers. Also there is less opportunity to encourage transfer of skills between subjects-no recognition that what is learned in the library can be applied, for example, to use of resources in other departments. It must be emphasized that although there are examples of good practice in Scottish 
schools, that is, using a cross curricular approach to develop information skills in all pupils, many schools are still taking the traditional approach (Gill, 1994).

Problems with Information Skills Development.

Many problems have been recognized in relation to skills development. The following may arguably be amongst the hardest to overcome:

- integrating information skills into the curriculum from primary to S6 and teaching them in a cross curricular way so that all subject areas are involved. Beare and Slaughter (1994) state that knowledge in schools tends to be compartmentalized into subject areas with water tight boundaries. It may be difficult to penetrate these boundaries with cross curricular approaches to information skills.

- the teacher-librarian relationship. The professional services which school librarians can provide to the development of the curriculum versus the "...innate tensions in the divide between the professions of librarianship/information science and teaching" can be problematic (MacLean, 1993, p. 26). These tensions tend to manifest themselves when librarians become involved with the 'teaching' of information skills if teaching is seen to be the exclusive domain of teachers. MacLean, a former school librarian herself, advises that a partnership between librarian and teacher should benefit the school and that "It should not be seen as an erosion of the importance of teachers if the school librarian is recognized as having an essential part to play in the curriculum planning." (MacLean, p. 32)

- teachers' own information skills. Poor information skills amongst teachers has been recognized as a problem by researchers (Best, 1990; Squirrell, 1990) and practitioners alike. For example, Cotterill (1991), a school librarian who runs induction lessons for first year pupils, states "I make sure that the subject staff stay in the library when I am briefing pupils...They may be embarrassed or surprised when they cannot help individuals [pupils] who request it...." (p. 47) This quote indicates that teachers are, perhaps uncomfortably, made to realize that their own information skills are lacking. It also shows a general lack of transfer and/or lack of information skills development in their own education.

Hopkins (1987) made some interesting observations:

[teachers]...tend to focus on materials to ensure that their students are 'busy'. They address goals literally but do not comprehend their underlying purpose...It is the acquisition of these principles [a critical appreciation of the curriculum] that is at the basis of information skills education, and they are not easily achieved by the bland use of workcard. (p. 89)

This begs the question 'how well equipped with information skills are teachers and to what extent will their own abilities and perceptions help or hinder the development of skills in their pupils?' If pupils are expected to develop search strategies, for example, then teachers' own information skills and attitudes will play a large part in developing skills such as identifying key words and using Boolean logic.

Teachers themselves need to be information literate (Hall, 1986) and need to be able to apply this information literacy to the principles of their curriculum. As stated by Olen (1994) teachers need to develop information skills in themselves first before they can develop them in their pupils. This is echoed in research by Best (1990) who states "If students leave college with memories of the library as forbidding and stressful...they cannot be expected to promote positive attitudes to library use amongst their pupils." (p. 15)

This theme of past experiences impacting on how teachers teach is also addressed by Britzman (1991) who says "The story of learning to teach begins actually much earlier than the time one first decides to become a teacher...They bring to their teacher education their educational biography." (p. 3) Any misconceptions about the importance and relevance of information skills 
picked up by future teachers during primary, secondary and higher education especially, may be fed back into the system. Conversely, it can be hypothesized that successful development of teachers' own information skills whilst they are learners, will result in more effective development of skills in their pupils.

\section{THE STUDY}

The study investigates issues surrounding the information skills of students training to be secondary school teachers.

\section{Setting the Scene}

In Scotland there are 2 routes to becoming a secondary school teacher. These are: Bachelor of Education [four year] and Post Graduate Certificate of Education [one year].

PGCE secondary school training is divided between college based and school based experience. The time in college is spent preparing student teachers for all aspects of teaching. In schools they are expected to develop teaching skills and become familiar with school routines and arrangements. Student teachers have a series of placements in secondary schools.

School librarians follow a general librarianship course; either a four-year Bachelor of Arts or a one-year Post Graduate course. There may not be a specific 'school librarian' element within the course but students can investigate issues pertaining to school librarianship by focusing project work and their dissertation. Figure 1 represents the broad context within which the present study is being undertaken.

The model, developed in 1995, is two dimensional: it represents the linear progression of student teachers from pupil to teacher and it also aims to illustrate the possible cyclical effect of information skills input, or the lack of it. This cyclical effect is interesting as teachers are the interface between their subject knowledge and the broader learning experience of their pupils. If teachers, as role models, are themselves uncomfortable using information, what impact could this have on pupils?

\section{Methodology}

The focus of this paper is a study within a study. It is part of a larger project which will, in its final phase, involve carrying out case study work in the classrooms of secondary school teachers to highlight issues relating to the application of their own information skills in the teaching situation. The following discussion highlights the results of the initial phase of the larger study in which semistructured interviews with representatives of a number of key groups were set up in order to get a rounded picture of the perceptions and expectations of information skills development in student teachers. Interviews were held as follows:

- Teacher Education Institute interviews.

10 lecturers from one TEI. In addition interviews were carried out with TEI librarians.

- Secondary school interviews.

14 teachers from a variety of subject specialisms and six school librarians. In addition, three members of senior management were interviewed.

- School Library Service.

Librarians at the local schools' library service based in Aberdeen.

\section{- Student teachers.}

A small number of student teachers were interviewed while they were on their second school placement. In the following discussion each student teacher is identified by a code: ST1, ST2 and so on. 


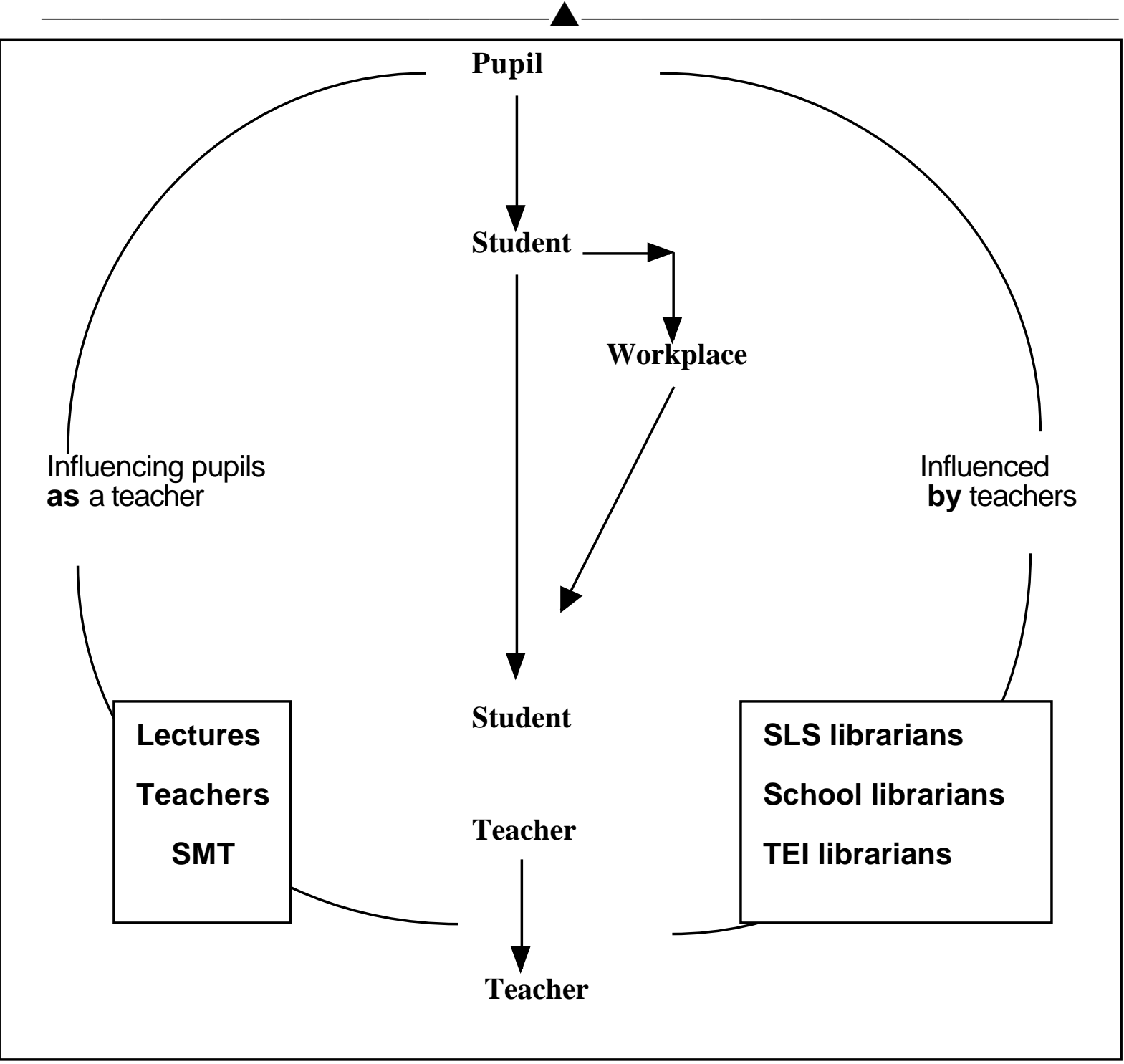

Figure 1: Information Skills Cycle

According to TEI course documentation (Northern College, n.d. approx. 1994), the first teaching placement was seen as a time for students to become familiar with school routine and to watch teachers working in the classroom. During the second placement student teachers take on a more active teaching role; this seemed an ideal time to ask student teachers to reflect on their teaching and their information skills

\section{FINDINGS}

A number of issues were identified which tend to focus around 3 main themes: expectations and perceptions; information skills and; the course and teaching practice.

\section{Expectations and perceptions.}

This section makes reference to data gathered both from interviews and relevant documentation. Lecturing staff were asked to talk about their expectations of student teachers' information skills: several comments were made which reinforced the fact that their expectations of 
the student teachers' information skills capabilities were probably too high. One explanation was that because they were Post Graduate students they ought to have developed the skills during their first degree.

Teachers generally expected student teachers to gain a certain level of competence in teaching ability during their second teaching practice placement in schools but little consideration was given to any expectations of student teachers with regard to their ability in using information to continue their own learning. Thoughts about need for student teachers to be able to select appropriate resources for teaching purposes was varied; at best the criteria for selection which student teachers were expected to use were those connected with the level of the material, an awareness of sexism, racism and so on. Teachers themselves often commented that all the material they needed to teach classes was held within their own departments. This suggests that these teachers working with student teachers may have lower expectations about the need for student teachers to perform tasks laid out in the TEI curriculum guidelines, which state that student teachers should be able to "select and use in a considered way a wide variety of resources," (Northern College, n.d. approx. 1994, p. 4) and to "be aware of sources of help and expertise within the school and how they can be used [e.g.,] resources including the library..." (p. 6)

School librarians also thought that they should be able to expect students to use the library more effectively than they could. One said "Many have little or no knowledge of information skills. Little attention seems to be paid to the teaching of information skills in preparation for teaching practice." Another stated "We had an S1 science class down with a student teacher for their information skills lesson. The student teacher didn't know herself what the pupils were learning about."

Librarians at teacher education institutes all gave a very similar view of the students. They were seen as 'know it alls' who used the library much less often than PGCE (Primary) students. The librarians also indicated problems with lecturing staff namely, communication and problems of cooperation with regard to setting up, running and evaluating information skills programs with input from the library. This problem with lecturing staff is highlighted in the literature by Bines (1992) who recommended that lecturers and librarians should work closer together.

Student teachers generally felt that lecturers' expectations of them were high-sometimes unrealistically high. "They presumed that you knew these things. They didn't start anything over again...they did assume a lot about skills. They assumed that each mature student was expert in their subjects, which is totally ridiculous...." This feeling perhaps signals a lack of confidence in the student teachers as learners and information users.

The School Library Service librarians found that a number of the PGCE (Secondary) students came across as having a 'know it all' attitude. They also found that very few of the student teachers training to become secondary school teachers used the library service. The few who did use it generally came armed with a book list whereas the primary school student teachers research a subject. This perhaps said something about the teaching methods adopted by the TEI.

\section{Information Skills}

Lecturing staff agreed with Britzman (1991) that student teachers are influenced by their previous experiences in education. One said that students coming from particular institutions of higher education had poorer skills than others. This appears to back up Gill's findings (1994) that there may be poor transfer of skills from secondary school to higher education.

Another lecturer perceived little difference between the skills of those coming straight from school to do the BEd course and those of students coming from higher education. The respondent had expected that students coming from higher education would have more skills than those coming from school because they had more study experience.

There can be a number of possible explanations for this observation, including:(a) a transfer problem from both secondary school and first degree level; (b) skills taught in secondary education and at first degree level are inappropriate for post graduate study-perhaps indicating a general lack of communication between educational institutions; and (c) students at first degree level are either not expected to, or not able to, or not inclined to, develop skills in any more depth than those at secondary school.

One lecturer stated that students had difficulty focusing on information. The comment was made that they could not see the wood for the trees. This reveals a feeling that students' information 
skills are sometimes not well developed. They were seen to be unable to sift through the mass of information to find the relevant piece. Another lecturer said: "Students are often not restricted by lack of intelligence but by how well their information skills are developed." One TEI librarian could not recall meeting any of the students and the college had no input into their information skills. The library wanted to target the group but found it difficult to find a suitable mechanism to gain access to the group in order to find out their needs. Another TEI librarian was eager to make an input but found it hard to pitch it at a level acceptable to all the students. They felt that eventually they would have to move towards 'just giving a handout'.

There was a general impression that student teachers were not as well equipped with regard to information skills as they needed to be and there was concern about how the student teachers could teach information skills to pupils if they were poor at handling information themselves.

Selecting materials for the classroom is one way in which student teachers are required to use information skills. When asked about this, one teacher said that she selected materials for student teachers-"putting things in boxes"- the student selected from there. This teacher stated "There is no real need for them to practice selection in the classroom but they are probably given practice in the college." A Principal Teacher was quite embarrassed to admit that she even chose materials for her staff to teach with. The example she gave was of putting materials in a box for a supply teacher.

Most students found it difficult to take a holistic view of the information handling process and wanted to break any definition of information skills into component parts-finding information, evaluating information and so on. They seemed to be unaware of the links, not appreciating, for example, how evaluating the information seeking process would help the preparation for another information seeking task. It also seemed alien for them to see information skills as generic skills and each respondent could only really focus on how they might fit into their own subject. The problems associated with the compartmentalization of knowledge into subject areas is outlined by Britzman (1991); respondents also compartmentalized skills. This may reflect the training to be a secondary school teacher - the need to be within the boundaries of a subject. Interestingly, reference was made on several occasions to the positive factors associated with the primary school model of teaching where a more holistic approach to learning may be easier to achieve. ST6 said that in primary, pupils have a more holistic view of learning from his experience of them on placement. He said: "It's great to see, it really works, and then you come up here and suddenly everything has its own niche. The whole secondary structure is like that."

Student teachers had mixed experiences in Higher Education. Two of them related information skills to IT experience but were unable to elaborate about specific features of using CDROM for searching for information even when pressed. ST2 said that he had to use information skills because of the type of degree he did. He had studied with the Open University and said "I had to find out what libraries to go to for what information...I learned that by trial and error-by going to the wrong places first!" ST4's experience of information skills at university was that they were told to write essays. She remembered a library tour and being told "this is where you will find your stuff." This attitude of the librarian had obviously instilled in the student that there was a particular part of the library housing materials for her subject. This attitude would not help to create a cross curricular approach in school. She was not confident about approaching the librarian. ST5 said that he could remember no information skills teaching in HE and that their had been no input from the librarian. Both these students regarded the librarian as provider not facilitator. Their difficulties started when they had to search for material themselves. Neither of them could see this and relate it back to their own lack of information skills.

On the other hand, ST6 did make the connection between information skills and his ability to find information, albeit late in his education. He said that in third year after "fumbling" his way around the library they were given a course "...in information retrieval?...I can't remember...at the time that seemed almost flippant but in years to come I found that was absolutely invaluable."

Students were asked about the information skills element in their teacher training course. ST3 said that they were told to look out for certain things when selecting classroom material. They were told about good books for their subject and about avoiding "-isms" (racism and so on).

ST4 said that they were only taught about things like learning processes and talking about how pupils assimilate information-so nothing about how they, the student teachers, learn and nothing specifically about information skills. Students were then asked to comment on their information skills in relation to use of the library. ST2 said: 
when you go for the library lecture it's very much treated as a peripheral. Use it if you need it and if you don't think you need it well...That's the attitude of the whole course though. You're shown it because you may need it but it's not stressed that you will and should need it.

Student teachers were asked to discuss any problems they felt they had with regard to information skills. Apart from one respondent, they found it difficult to identify problems they had which were related to information skills. Broad examples of possible problems, for example, 'any problems when you are, say, in the library looking for information', had to be given to start them off. ST2 said that:

to be truthful, if I was to go across to the library here [TEI library] [to use] the CDROM, someone would have to...show me how to use it...I can use a computer, the mouse and that but it is how the stuff works that I can't do.

ST2 was pressed further to explain his problem and it was clear that he was uncomfortable with search strategies and so on. It took a lot of effort for him to be able to articulate his problem as he obviously did not realize where the problem lay. This was part of a general difficulty student teachers appeared to have in trying to explain what they cannot do and are uncomfortable about.

ST2, when asked to comment on his own information skills (these were explained by showing Marland's (1981) list and talking around the idea of information skills) went through each skill individually:

What should I make a record of? I haven't got a clue because no-one has ever said. I have made my own filing system, my own information base. If it is wrong then well, I still use it! Have I got the information I need? I don't know until I put it in for assessment.

This highlighted interesting issues; he assumed that there was one 'right' type of filing system not one to suited how he works; also he did not realize that 'Have I got the information I need?' is not something you have to wait until you get your assessment back to think about. He gave no thought to evaluating and reflecting on a task, no self assessment, even though it is expected that their pupils will do it.

ST4 made a very interesting and perceptive point about the dilemma of being teacher and learner:When I am at college as a learner I'm allowed to make mistakes...if my information isn't there then it is my fault and I am getting marked down for it or if it isn't laid out well then I'm getting marked down for that. Here [at school] it has to be just so-or your kids are going to pick holes in it....

Students were asked to comment on teaching information skills to pupils. ST5 focused on practical skills and when pressed to talk about information skills said: "I'd say look I've got a book here, or, ask them 'How would you find out about this?' and then if they have any ideas, like going to the library, which would be obvious, then they'd go off and do it." So little follow through here...the librarian's problem now!

In general, students had problems expressing their own information skills experiences. They seemed more comfortable talking from the classroom perspective and what they would expect of the pupils.

\section{The Course and Teaching Practice Experience}

Lecturers were quite clear that student teachers were influenced by the departments to which they were attached and that "students often feel restricted on placement." A student was told that she could not use a particular teaching method because "...it's always been done this way here." However, one student felt she had been influenced positively by a school she had taught in. It was trying to develop a cross-curricular information skills approach. She saw benefits to pupils and said 
that once qualified she would try to do likewise. She, however, was aware that this might be problematic if the school was less innovative.

Students were asked about their induction to the schools. These appeared to vary from a "whistle stop" tour, to a course involving a day shadowing a pupil, time spent on the school ethos and structure and a general information booklet.

When discussing information skills development of pupils many TEI lecturers made little reference to the school library unless prompted to do so. The general consensus of school librarians and lecturers about use of the school library by student teachers was that it would depend on the department to which she/he was attached. ST2 said that he thought that co-operation between librarian and teachers was important and that teachers needed to be more flexible. However when it came to the crunch he said: "Well, but contrary to my first statement about co-operation-I think it [resources] should be in the department." When asked why, he said, "[the] resources are at my hand. I can say: On this shelf there are books on graphics. Look...on page whatever. That to me is positive encouragement to a kid." But not exactly developing information skills in his pupils!

An indicator of the importance of highlighting information skills to students was revealed by ST3, who said that he had "not been taken into their [the department] confidence enough to know what was in their development plan" so he did not know if information skills were in the development plan or not. This shows a lack of getting the student involved and means that he is simply spoon-fed what the teacher considers he should have. He is not allowed to interpret the ethos of the department by seeing the documentation that goes along with it. This was a fairly light hearted comment but with important issues underlying it.

Students were unaware of any committees in their placement schools dealing with or related to information skills. One guessed that each department was on its own but that it would vary from school to school and would depend on the teachers. ST5 said he was surprised at how many children used the library. When asked if he encouraged his pupils to use the library he said that he would like his pupils to use the library but said: "we've got other things to do in class. So I'd rather they didn't do it in class time." ST1 was questioned about the information skills of pupils under her supervision. She said that pupils had to use the telephone directory and she was amazed that they did this poorly. She asked if that was an information skill-she was very unclear about what information skills were and their application to everyday tasks.

ST4, saw problems of transfer of skills of her pupils when an example was cited. She asked her class to do a simple comprehension but they got stuck. She thought that this was because they felt the task was out of context, i.e., she was not an English teacher. She was asked if she felt confident about teaching these skills and she laughed and admitted that she was teaching things that she could not do herself. She was poor at lesson planning she said and also about knowing the difference between aims and objectives. She said:

I think...the idea of putting things into your own words, taking notes and helping the information:to sink in because you've had to rephrase it is something that I'm not very good at, but because I'm not very good, I see the importance of getting them to do it.

These findings have concentrated on three themes emanating from the interviews. These themes suggest indicators of positive and negative influences on information skills development within the student teachers professional framework, and a discrepancy between the skills required to underpin the ethos of the formal curriculum and the students' broad appreciation of the nature of these skills and their application in the curriculum.

\section{CONCLUSIONS}

If it [a curriculum] cannot change, move, perturb, inform teachers, it will have no effect on those whom they teach. If it has any effect on pupils, it will have it by virtue of having had an effect on teachers." (Bruner, 1977, p. xv)

Results indicate three issues: first, a lack of understanding about the term information skills; second, a general inability to view information skills as generic skills in a holistic way; and third, an 
inability and/or lack of opportunity, in many cases, to reflect on abilities and shortfalls. Each group of respondents saw lack of information skills in others but were mostly unable to focus on their own. This third issue gives most concern as the first two issues might be lessened if the third issue was tackled.

These people do not need a crash course in librarianship. They need to be information literate. The study, however, suggests that the issue is bigger than this: before they know how to become information literate, they first need to appreciate why they need to become information literate. They must develop the ability to verbalize their needs and for this to happen they need time to reflect on what learning means to them in order for these needs to be clarified. Being taught about the learning process in connection with your job as a teacher is quite different from internalizing the information and applying it in a personal way.

So where is the time for this reflection? The study so far indicates that it does not exist. Although the appropriate skills are recognized within curriculum guidelines, no time is apparently dedicated for ownership and review of these information skills. Teacher educators have the ideal opportunity to help student teachers gain competence and confidence in information skills because of the emphases in the curricula, both at school and TEI. The curriculum policy documentation and the approach of the course content need to mirror each other. TEI educators are still teaching learners-subject expertise alone does not make them teachers or effective learners. As Brake (1980) said: "Initial teacher and librarian education must propagate the idea that education, particularly for professionals, is a continuing process." (p. 40)

Reflection is part of learning and teachers, more than other learners, are, by virtue of their profession, involved in the learning process-for themselves and for their pupils. Teachers need opportunities in a supportive environment to develop their own information skills; they also need to recognize themselves as a strange amalgam of teacher and learner. "Gatekeepers to knowledge" is one view of teachers but in the era of independent learning this image does not sit comfortably. Looking to the future Beare and Slaughter (1994) say:

[T]he knowledge structures which come...in the form of stereotyped subjects and disciplines (and schools are full of them!) can work against the development of optimism and empowerment...they confront the learner with pre-givens requiring accommodation and acceptance, not reconceptualisation and creativity. (p. 127)

This view of formal school learning is also addressed by Vaill (1996) who suggests that it is a control system which does not prepare us for the "messy learning world" we live in. He suggests a need to "rethink the kind of learning, in content, form and underlying philosophy." (p. xvi) This paper would agree that if information literate teachers and information literate pupils is the desired outcome, then some of the structures within which they learn need to reflect more upon the "messy learning world" within which we undoubtedly exist and reassess their direction and approach.

\section{REFERENCES}

Adey, K. (1993). Integrating information literacy into teacher education. In Information literacy. The Australian Agenda. Conference proceedings conducted by the University of South Australia Library. Adelaide College of TAFF, Adelaide, 2-4 December 1992. (pp. 78-81). Adelaide: University of South Australia.

American Library Association. (1989). Presidential committee on information literacy. (Final Report). Chicago: ALA.

Avann, P. (Ed.) (1985). Teaching information skills in primary schools. London: Edward Arnold.

Beare, H. \& Slaughter, R. (1994). Education for the 21 st century. London: Routledge.

Best, R., Abbott, F. \& Taylor, M. (1990). Teaching skills for learning. (Library and Information Research Report 78). London: British Library.

Bines, H. (1992). The future of teacher education. Education Libraries Journal, 35(2), 1-8.

Books in schools. (1992). (Book Trust Report No 1). London: Book Trust.

Brake, T. (1980). The need to know: teaching the importance of information: Final report. (British Library Research \& Development Report 5511). London: British Library. 
Britzman, D P. (1991). Practice makes practice. A critical study of learning to teach. Albany: State of University of NY Press.

Bruner, J. S. (1977). The process of education. Cambridge, MA: Harvard University Press.

California Media and Library Educators Association. (1994). From library skills to information literacy: A handbook for the 21 st century. Castle Rock, CO: Hi Willow Research \& Publishing.

Carter, C. \& Monaco, J. (1987). Learning information technology skills. (Library and Information Research Report 54). London: British Library.

Cotterill, G. (1991). Teaching teachers to use the library. The School Librarian. 39(2), 47.

Dubber, G. (1995). SLA guidelines. Teaching information skills. Swindon: School Library Association.

Eisenberg, M. B. \& Brown, M. K. (1992). Current themes regarding library and information skills instruction: Research supporting and research lacking. School Library Media Quarterly, 20(2), 103-109.

Gill, S. (1994). Bridging an information skills gap of Scottish pupils going on to higher education: the background of current research in this area. School Library Group (Scottish Branch) News, (9), 3-4.

Greensfeld, H. and Friedler, Y. (1996). In Y. J. Katz (Ed.) The impact of information technology. From practice to curriculum. (pp. 101-107) London: Chapman and Hall.

Hall, N. (1986). Teachers, information and school libraries. Paris: UNESCO.

Healey, M. (1992). Curriculum development and 'Enterprise': group work, resources based learning and the incorporation of transferable skills into a first year practical course. Journal of Geography in Higher Education, 16(1), 7-19.

Heaney, P. (1986). Information skills in the primary school. Greater Manchester Primary Contact. 49(1), 68-78.

Herring, J. (1996). Teaching information skills in schools. London: Library Association.

Hopkins, D. (Ed.) (1987). Knowledge, information skills and the curriculum. (Library and Information Research Report 46). London: British Library.

Hounsell, D. and Martin, E. (1983). Developing information skills in schools. (Library and Information Research Report 9). London: British Library.

Howard, J. (1991). Information skills and the secondary curriculum. (Library and Information Research Report 84). London: British Library.

Irving, A. (1992) Information skills across the curriculum, INSPEL, 26(3), 224-233.

Kuhlthau, C.C. (1995). The process of learning from information. School Libraries Worldwide, 1(1), $1-12$.

Labour market and skills trends. 1996/1997. (1996) Nottingham: Skills \& Enterprise Network.

Lincoln, P. (1987). The learning school. (Library and Information Research Report 62). London: British Library.

MacLean, G. (1993) Professional partners in education:paradoxes for the school librarian. Scottish Educational Review, 25(1), 26-33.

Marland, M (Ed.). (1981). Information skills in the secondary curriculum. (Schools Council Bulletin 9). London: Methuen Educational.

Olen, S. (1994) A transformation in teacher education: or how can disadvantaged teachers become information literate? In Proceedings of the International Association of School Librarianship: University of Pittsburgh, Pittsburgh, Pennsylvania, July 17-22, 1994 (57-62). Kalamazoo, MI: IASL.

PGCE (Secondary) School Experience Book. (n.d.) Aberdeen: Northern College (approx. 1994).

Ridgway, J. \& Passey, D. (1996). In D. Watson \& D. Tinsley (Eds.) Integrating information technology into education (pp. 59-72) London: Chapman \& Hall.

Rogers, R. (Ed.). (1994). Teaching information skills: Review of the research and its impact on education. London:Bowker.

Scottish Examination Board. (1995). Scottish certificate of examination. Conditions and arrangements. Dalkeith: Scottish Examination Board.

Scottish Office Education and Industry Department. (1991). Information and study skills in Scottish secondary schools. Edinburgh: SOEID.

Scottish Office Education and Industry Department. (1993a) Environmental Studies 5-14 National Guidelines. Edinburgh: SOEID. 
Scottish Office Education and Industry Department. (1993b). Structure and balance of the curriculum. 5-14 Guidelines. Edinburgh: SOEID.

Scottish Office Education and Industry Department. (1993c). Guidelines for teacher training courses. Edinburgh: SOIED.

Scottish Office Education and Industry Department. (1996) Higher Still. Core skills consultation document. Edinburgh: SOEID.

Squirrell, G et al. (1990). Acquiring knowledge in initial teacher education: reading, writing and practice and the PGCE course. (Library and Information Research Report 79). London: British Library.

Times Educational Supplement (Scotland), (1994, November 1). pp. 1, 14.

Vaill, P. B. (1996). Learning as a way of being. San Francisco: Jossey Bass.

Wild, M. (1996). Technology refusal: rationalising the failure of student ad beginning teachers to use computers. British Journal of Educational Technology, 27(2), 134 -143.

Winkworth, F V. (1977). User education in schools: a survey of the literature on education for library and information use in schools. (British Library Research and Development Report 5391). London: British Library. 